\title{
INITIAL GROWTH IN MAIZE IN COMPLIANCE OF AZOSPIRILLUM BRASILENSE INOCULATION AND NITROGEN RATES
}

\author{
CRESCIMENTO INICIAL DO MILHO EM FUNÇÃO DA INOCULAÇÃO DE \\ AZOSPIRILLUM BRASILENSE E DOSES DE NITROGÊNIO
}

\author{
Elisa Pereira de OLIVEIRA'; Matheus Gustavo da SILVA²; Paulo Eduardo TEODORO³ \\ 1. Universidade Estadual Paulista "Julio de Mesquita Filho", Campus Botucatu, Botucatu, SP, Brasil; 2. Universidade Estadual do Mato \\ Grosso do Sul, Unidade Universitária de Aquidauana, Aquidauana, MS, Brasil; 3. Universidade Federal do Mato Grosso do Sul, \\ Campus de Chapadão do Sul, MS, Brasil. eduteodoro@hotmail.com
}

\begin{abstract}
Investigate the effects of the interaction between nitrogen fertilization and inoculation with diazotrophic bacteria becomes important, especially for maize, highly exacting in $\mathrm{N}$. Thus, the aim of this study was to evaluate the initial growth of maize in compliance $A$. brasilense inoculation and nitrogen rates. The experiment was conducted in a greenhouse, in Mato Grosso do Sul State University, Aquidauana University Unit, between the months of march and April of 2014. It was used completely randomized design in a 2x4 factorial arrangement with four replications. The treatments consisted of the absence and presence of inoculation with A. brasilense and four levels of nitrogen fertilization $\left(0,25,50,100 \mathrm{~kg} \mathrm{ha}^{-1} \mathrm{~N}\right)$. At 40 days after sowing the following variables were evaluated: leaf area, plant height, stem diameter, dry mass of shoot and of root. There was interaction between doses of nitrogen and inoculation with A. brasilense for most of the evaluated variables. Inoculation with A. brasilense provides improvements in the establishment and initial development of maize. In the presence of inoculation with A. brasilense, the development of maize increases linearly the administration of the nitrogen doses.
\end{abstract}

KEY WORDS: Nitrogen fertilization. Diazotrophic bacteria. Inoculant. Zea Mays L.

\section{INTRODUCTION}

Maize (Zea mays L.) is a cereal of great economic importance in the world. Brazil is the third largest producer of this grain, the national production of maize in the harvest reached a volume of approximately 81.5 million tons (CONAB, 2014). The economic importance of maize is characterized by its use diversity, ranging from human and animal feed to high technology industries, such asthe ethanol production ones (NERI et al., 2005; TEODORO et al., 2015).

Maize is a demanding crop when it comes to soil fertility, given the fact that it requires a great amount of nitrogen $(\mathrm{N})$, it represents one of the highest costs to the producers due to the high demand for nitrogen fertilizers (MALAVOLTA, 2006). Although $\mathrm{N}$ is present in the atmosphere, it is not available in an assimilable form to the plants. Thus, its fixation in the soil can occur by means of electric discharges and industrial or biological processes (CARMO et al., 2012). Among these processes, the biological nitrogen fixation (BNF) accounts for about $60 \%$ of all $\mathrm{N}$ accumulated by the plants, being of great support for the increased yield, in addition to being an ecological and more economical alternative to the nitrogen fertilizers (BODDEY et al., 2001).
Bacteria from the 5 genus can be inoculated in the plants of agronomic interest, stimulating their growth throught multiple mechanisms, which include phytohormone synthesis, nitrogen nutrition improvement, stress mitigation and the biological control of the pathogenic microbiota. (BASHAN; BASHAN, 2010; MORAIS et al., 2016). Azospirillum genus (gram-negative, aerobic or microaerophilic bacteria) belongs to the Alfaproteobacterias class, Rhodospirillaceae family, and it is currently possible to find more than 200 of its variations in the gene bank (QUADROS et al., 2014).

Nitrogen fixation in the plant during the plant-bacteria association is a process in which bacteria only provide fixed nitrogen if sources of carbon and energy are sufficiently available (CHUBATSU et al., 2012). Thus, it is important to investigate the interaction effects between nitrogen fertilization and inoculation with diazotrophic bacteria, especially for the maize crop, which presents high demands for N. In this sense, we emphasized the hypothesis on the extent to which it would be feasible to substitute mineral nitrogen by the Azospirillum brasilense inoculation. Thus, this study aimed to verify the initial maize growth in compliance with the A. brasilense inoculation and nitrogen rates. 


\section{MATERIAL AND METHODS}

Trial was carried out in greenhouse at State University of Mato Grosso do Sul, Unit of Aquidauana, from March to April, 2014. Region climate is classified according to Köppen's classification as Aw, tropical sub-humid, with rainy summer and dry winter, average annual rainfall of $1,200 \mathrm{~mm}$ and maximum and minimum temperatures of 33 and $19{ }^{\circ} \mathrm{C}$, respectively. Region soil was classified as Red Ultisol dystrophic sand texture.

Agricultural greenhouse where the trial was carried out has a galvanized arc structure, chapel type, with a low-density polyethylene film (LDPE) of 150 microns thickness, zenith aperture and thermo-reflective screen (50\% shading), having 6.4 $\mathrm{m}$ wide by $18 \mathrm{~m}$ long, with $4 \mathrm{~m}$ height under.

A completely randomized design was used in a $2 \times 4$ factorial scheme, with four replications. The treatments consisted of combining absence and presence of $A$. brasilense inoculation and four nitrogen fertilizer rates $\left(0 ; 25 ; 50 ; 100 \mathrm{~kg} \mathrm{ha}^{-1}\right.$ of $\left.\mathrm{N}\right)$.

The plants were conducted in plastic containers with a capacity of $5 \mathrm{~L}$ previously disinfected with solution containing $40 \%$ alcohol + $10 \%$ formaldehyde $+20 \%$ sodium hypochlorite and air dried. Soil for filling the pots was collected and later air-dried and sifted for packaging in the pots. Soil chemical analysis was performed, from which singe samples were taken from the $0-20 \mathrm{~cm}$ layer, forming the composite sample that was sent to the laboratory.

The soil showed the following chemical characteristics: $\mathrm{pH}\left(\mathrm{CaCl}_{2}\right)=4.3 ; \mathrm{OM}=3 \mathrm{~g} \mathrm{dm}^{-3} ; \mathrm{P}$ $=0 \mathrm{mg} \mathrm{dm}{ }^{-3} ; \mathrm{Ca}=5$ mmolc dm$^{-3}, \mathrm{Mg}=4$ mmol $_{\mathrm{c}}$ $\mathrm{dm}^{-3}, \mathrm{~K}=0,8 \mathrm{mmol}_{\mathrm{c}} \mathrm{dm}^{-3}, \mathrm{Al}=14 \mathrm{mmol}_{\mathrm{c}} \mathrm{dm}^{-3}$, $\mathrm{H}+\mathrm{Al}=32 \mathrm{mmol}_{\mathrm{c}} \mathrm{dm}^{-3}$, and $\mathrm{CEC}=42 \mathrm{mmol}_{\mathrm{c}} \mathrm{dm}^{-3}$. Dolomitic limestone $(28 \% \mathrm{CaO}, 20 \% \mathrm{MgO}$ and $75 \%$ relative total neutralizing power - RTNP) was applied to raise base saturation to $60 \%\left(2.11 \mathrm{t} \mathrm{ha}^{-1}\right)$. So that there was chemical reaction in the soil, it was moistened to the field capacity and conditioned under plastic canvas for 20 days. Fertilization was carried out according to the soil analysis using 120 $\mathrm{kg} \mathrm{ha}^{-1} \mathrm{P}_{2} \mathrm{O}_{5}, 180 \mathrm{~kg} \mathrm{ha}^{-1} \mathrm{~K}_{2} \mathrm{O}$ (RAIJ et al., 1996) and nitrogen fertilization according to treatments using urea at sowing.

Maize seeds were inoculated with the commercial product AZOMAX, manufactured by Novozymes company, containing ABV-5 and ABV6 strains from $A$. brasilense bacterium at a minimum concentration of $3 \times 10^{8}$ viable cells $\mathrm{mL}^{-1}$. For each hybrid, the manufacturer's recommended dose equivalent to $150 \mathrm{~mL}$ of the commercial inoculant was applied to 60,000 seeds.

We used in this trial the Maximus single hybrid, manufactured by the Syngenta company. Seeding was done with four seeds per pot, placed at $3 \mathrm{~cm}$ deep. Thinning was performed 10 days after sowing (DAS), maintaining two plants per pot. At 10 days after emergence (DAE), due to the low level of phosphorus in the soil $\left(0 \mathrm{mg} \mathrm{dm}{ }^{-3}\right)$ fertilization with monobasic potassium phosphate solution $\left(\mathrm{KH}_{2} \mathrm{PO}_{4}\right)$ was carried out at rate of $658.5 \mathrm{mg} \mathrm{mL}^{-1}$ by applying $100 \mathrm{~mL}$ per pot (equivalent to $1,317 \mathrm{~kg}$ ha $^{-1}$ ).

Evaluations were carried out at 40 DAS (V8 stage in which the number of grain rows), determining the plant height using graduated ruler for measuring from the ground base until the last completely developed leaf insertion; stem diameter, measured in the neck region using a digital caliper; leaf area, estimated by measuring length and width of the +3 leaf, according to the method described by Pereira (1987): LA $=\mathrm{L} \times \mathrm{W} \times 0.75$, where $\mathrm{LA}$ is leaf area; $\mathrm{L}$ is the leaf +3 length; $\mathrm{W}$ is the width +3 length; and 0.75 is the correction factor for leaf area of the crop.

The plants were removed from the pots and partitioned into shoot and root system. Root system was washed in running water, using a fine mesh sieve to avoid finer root losses. Leaves, stems and roots were separated, packed in paper bags and dried in an oven with circulation at $65^{\circ} \mathrm{C}$ for 72 hours, and then the dry mass of shoot and root were recorded.

Analyzed variables were initially submitted to the Shapiro-Wilk and Bartlett tests to verify the normality of the residues and to test the homogeneity between the variances, respectively. Subsequently, data were submitted to analysis of variance, the qualitative factor (absence and presence of the inoculation) being submitted to the comparison of means by the Tukey test and the quantitative ( $\mathrm{N}$ rates) to the polynomial regression analysis. The best adjusted equation was chosen according to the coefficient of determination and the regression coefficients significance, tested by the $\mathrm{t}$ test corrected based on the residues of the analysis of variance. All the analyzes were performed using Sisvar statistical software (FERREIRA, 2011).

\section{RESULTS AND DISCUSSION}

There was significant interaction $(\mathrm{p}<0.01)$ between $A$. brasilense inoculation (I) and nitrogen rates $(\mathrm{N})$ on all variables evaluated, except for the 
Table 1. Values of F calculated for the variables plant height (PH), stem diameter (SD), leaf length (LL), leaf width (LW), number of leaves (NL), leaf area (LA), dry mass of shoot (DMS) and dry mass of roots (DMR) in compliance of A. brasilense inoculation (I) and nitrogen rates (N).

\begin{tabular}{lllll}
\hline Variable & Inoculation & Nitrogen & I x N & CV (\%) \\
\hline LA & $32.02^{*}$ & $35.94^{*}$ & $9.52^{*}$ & 16.23 \\
PH & $10.72^{*}$ & $12.52^{*}$ & $5.73^{*}$ & 11.19 \\
SD & $10.42^{*}$ & $17.91^{*}$ & $2.16^{\text {ns }}$ & 11.86 \\
DMS & $69.20^{*}$ & $65.40^{*}$ & $18.69^{*}$ & 18.04 \\
DMR & $32.99^{*}$ & $37.95^{*}$ & $7.11^{*}$ & 17.14 \\
\hline
\end{tabular}

ns, *, **: not significant, significant at 5 and $1 \%$ probability by the $\mathrm{F}$ test, respectively; $\mathrm{CV}$ : coefficient of variation.

A. brasilense inoculation provided the highest values for leaf area (Table 2) and plant height (Table 3) only when combined with the rate $100 \mathrm{~kg} \mathrm{ha}^{-1}$ of $\mathrm{N}$. In the absence of inoculation, there was a quadratic adjustment in response to $\mathrm{N}$ rates (with maximum point obtained with the approximate rate $60 \mathrm{~kg} \mathrm{ha}^{-1}$ of $\mathrm{N}$ ), while in the presence of inoculation there was a linear increase in plant height in both variables.

Table 2. Unfolding the significant interaction between nitrogen rates and A. brasilense inoculation for leaf area $\left(\mathrm{cm}^{2}\right)$ in maize.

\begin{tabular}{|c|c|c|c|c|c|c|}
\hline \multirow{2}{*}{ Inoculation } & \multicolumn{4}{|c|}{ Nitrogen Rates $\left(\mathrm{kg} \mathrm{ha}^{-1}\right)$} & \multirow{2}{*}{ Equation } & \multirow{2}{*}{$\mathrm{R}^{2}$} \\
\hline & 0 & 25 & 50 & 100 & & \\
\hline Absence & 61.7 & 109.9 & 125.0 & $114.3 \mathrm{~b}$ & $Y=63.26+2.093 x-0.0160 x^{2}$ & 0.987 \\
\hline Presence & 69.1 & 137.3 & 145.8 & $218.1 \mathrm{a}$ & $Y=81.90+1.386 x$ & 0.943 \\
\hline
\end{tabular}

Averages followed by different letters at each nitrogen rate differ from each other by the Tukey test at $5 \%$ probability.

Table 3. Unfolding the significant interaction between nitrogen rates and A. brasilense inoculation for plant height $(\mathrm{cm})$ in maize.

\begin{tabular}{lllllll}
\hline \multirow{2}{*}{ Inoculation } & \multicolumn{2}{l}{ Nitrogen Rates $\left(\mathrm{kg} \mathrm{ha}^{-1}\right)$} & \multirow{2}{*}{ Equation } & \multirow{2}{*}{$\mathrm{R}^{2}$} \\
& 0 & 25 & 50 & 100 & & 0.981 \\
& 11.3 & 13.9 & 14.6 & $13.3 \mathrm{~b}$ & $\mathrm{Y}=11.41+0.118 \mathrm{x}-0.0010 \mathrm{x}^{2}$ & 0.998 \\
\hline Presence & 11.9 & 14.0 & 15.8 & $19.1 \mathrm{a}$ & $\mathrm{Y}=12.00+0.072 \mathrm{x}$ & \\
\hline
\end{tabular}

Averages followed by different letters at each nitrogen rate differ from each other by the Tukey test at $5 \%$ probability.

Zemrany et al. (2006), Ramos et al. (2010), Hungria et al. (2010), Novakowisk et al. (2011), Kappes et al. (2013) and Quadros et al. (2014) observed an increase in the plant height in maize in response to the $A$. brasilense inoculation under different $\mathrm{N}$ rates. This may have occurred because there is a higher plant hormones production in the presence of $A$. brasilense, such as gibberellin (GA3 and GA1), which together with the use of $\mathrm{N}$, participates directly in the cell division and expansion and in the photosynthetic process (RIBAUDO et al., 2001; BASHAN et al., 2004).
The increase of $14 \%$ in the stem diameter of maize plants, provided by the $A$. brasilense inoculation is important because it minimizes possible situations of stress, since this organ is a source of carbohydrate reserves and lodging (Table 4). Ramos et al. (2010) and Hungria et al. (2010) also observed an increase of this variable in response to the $A$. brasilense inoculation. However, Repke et al. (2013) did not observe any inoculation influence on the maize development, including their stem diameter.

Table 4. Mean values for stem diameter $(\mathrm{cm})$ in maize plants in compliance of absence and presence of $A$. brasilense inoculation and regression equation in response to nitrogen rates.

\begin{tabular}{llll}
\hline Inoculation & Stem diameter $(\mathrm{cm})$ & Equation & $\mathrm{R}^{2}$ \\
\hline Absence & $8.08 \mathrm{~b}$ & $\mathrm{Y}=5.01+0.016 \mathrm{x}$ & 0.891 \\
Presence & $9.22 \mathrm{a}$ & $\mathrm{Y}=7.18+0.033 \mathrm{x}$ & 0.929 \\
\hline
\end{tabular}

Averages followed by different letters at each nitrogen rate differ from each other by the Tukey test at $5 \%$ probability. 
There was a linear increase in the stem diameter in response to $\mathrm{N}$ rates (Table 4), possibly because this nutrient increases $\mathrm{CO}_{2}$ assimilation and chlorophyll synthesis, providing greater photosynthetic capacity to plants and greater accumulation of carbohydrates, which are stored in this organ (CASTRO et al., 2008).

Under absence of $\mathrm{N}$ fertilization, there was no difference between the treatments for the production of dry mass of shoot (Table 5) and roots (Table 6). However, in the other rates A. brasilense inoculation provided the highest values for both variables. According to Ribaudo et al. (2001) and Quadro et al. (2014), this occurs because bacteria from the Azospirillum genus use $\mathrm{N}$ from nitrogen fertilization to assimilate carbon and multiply themselves faster, increasing the inoculation effects.

Table 5. Unfolding the significant interaction between nitrogen rates and A. brasilense inoculation for dry mass of shoot $(\mathrm{g})$ in maize.

\begin{tabular}{lllllll}
\hline \multirow{2}{*}{ Inoculation } & \multicolumn{2}{l}{ Nitrogen Rates $\left(\mathrm{kg} \mathrm{ha}^{-1}\right)$} & \multirow{2}{*}{$\mathrm{R}^{2}$} \\
& 0 & 25 & 50 & 100 & Equation & 0.999 \\
& 1.30 & $3.22 \mathrm{~b}$ & $4.18 \mathrm{~b}$ & $3.72 \mathrm{~b}$ & $\mathrm{Y}=1.31+0.092 \mathrm{x}-0.0007 \mathrm{x}^{2}$ & 0.974 \\
\hline Presence & 1.48 & $4.50 \mathrm{a}$ & $6.13 \mathrm{a}$ & $9.29 \mathrm{a}$ & $\mathrm{Y}=2.05+0.075 \mathrm{x}$ &
\end{tabular}

Averages followed by different letters at each nitrogen rate differ from each other by the Tukey test at 5\% probability.

Table 6. Unfolding the significant interaction between nitrogen rates and A. brasilense inoculation for dry mass of $\operatorname{root}(\mathrm{g})$ in maize.

\begin{tabular}{lllllll}
\hline \multirow{2}{*}{ Inoculation } & \multicolumn{2}{l}{ Nitrogen Rates $\left(\mathrm{kg} \mathrm{ha}^{-1}\right)$} & \multirow{2}{*}{ Equation } & \multirow{2}{*}{$\mathrm{R}^{2}$} \\
& 0 & 25 & 50 & 100 & & 0.999 \\
& 2.44 & $5.72 \mathrm{~b}$ & $8.15 \mathrm{~b}$ & $9.67 \mathrm{~b}$ & $\mathrm{Y}=2.42+0.155 \mathrm{x}-0.0008 \mathrm{x}^{2}$ & 0.994 \\
\hline Presence & 3.10 & $8.83 \mathrm{a}$ & $12.78 \mathrm{a}$ & $21.04 \mathrm{a}$ & $\mathrm{Y}=3.74+0.175 \mathrm{x}$ &
\end{tabular}

Averages followed by different letters at each nitrogen rate differ from each other by the Tukey test at $5 \%$ probability.

Under the absence of inoculation there was a quadratic adjustment in response to $\mathrm{N}$ rates (with the maximum point obtained with the approximate dose of 65 to $95 \mathrm{~kg} \mathrm{ha}^{-1}$ of $\mathrm{N}$ for the variable dry mass of shoot and root, respectively), while under the presence of inoculation there was a linear increase in the shoot (Table 5) and the root (Table 6) dry mass. Stancheva et al. (1992) stated that the increased dry mass of maize plants inoculated with A. brasilense occurs mainly under the presence of high $\mathrm{N}$ rates, which is related to the increased activity of photosynthetic enzymes and assimilation of this nutrient.

Reis Júnior et al. (2008), Hungria et al. (2010) and Quadros et al. (2014) have also observed an increase in dry mass of shoot and root of maize plants with A. brasilense inoculation. Bashan et al. (2004) pointed out that the plant hormones, especially indole acetic acid (IAA), excreted by bacteria from Azospirillum genus, play an essential role in promoting plant growth. Hartmann et al. (1983), Gopalswamy and Asekaran (1988) and Salamone and Dobereiner (1996) verified that maize seedlings with $A$. brasilense inoculation showed an increased in the number of root hairs, shapes and it also developed numerous primary and secondary lateral roots, which increase the nutrient uptake from the soil solution, favoring its development.

It is estimated that the use of inoculants containing selected strains of $A$. brasilense may save approximately US\$ 2 billion in chemical fertilizers, allowing reduction in transport costs, and leading to a reduction in pollution resulting from the production and use of N-fertilizers (HUNGRIA et al., 2010; COSTA et al., 2015). This effect may be beneficial to the crop during periods of water deficit, since maize is highly demanding in water and the increased specific root surface area allows a greater capacity of water and soil nutrients uptake.

\section{CONCLUSIONS}

Azospirillum brasilense inoculation provides improvements in the maize establishment and early development.

In the presence of Azospirillum brasilense inoculation, the development of maize increases linearly as a function of the nitrogen doses.

RESUMO: Investigar os efeitos da interação entre adubação nitrogenada e inoculação com bactérias diazotróficas tornou-se importante, sobretudo para a cultura do milho, altamente exigente em N. Assim, o objetivo deste trabalho foi verificar o crescimento inicial do milho em função de inoculação A. brasilense e doses de nitrogênio. $\mathrm{O}$ 
experimento foi desenvolvido em estufa agrícola, na Universidade Estadual de Mato Grosso do Sul, Unidade Universitária de Aquidauana, entre os meses de março a abril de 2014. Utilizou-se delineamento experimental inteiramente casualizado em esquema fatorial $2 \times 4$, com quatro repetições. Os tratamentos constaram da combinação da ausência e presença de inoculação com $A$. brasilense e quatro níveis de adubação nitrogenada $\left(0 ; 25 ; 50 ; 100 \mathrm{~kg} \mathrm{ha}^{-1}\right.$ de $\left.\mathrm{N}\right)$. Aos 40 dias após a semeadura foram avaliadas as seguintes variáveis: área foliar, altura de plantas, diâmetro do colmo, massa seca da parte aérea e massa seca das raízes. Houve interação entre doses de nitrogênio e inoculação com A. brasilense para a maioria das variáveis avaliadas. A inoculação com A. brasilense proporciona melhorias no estabelecimento e no desenvolvimento inicial do milho. Na presença de inoculação com A. brasilense, o desenvolvimento de milho aumenta linearmente a função das doses de nitrogênio.

PALAVRAS-CHAVE: Adubação nitrogenada. Bactérias diazotróficas. Inoculante. Zea mays L.

\section{REFERENCES}

BASHAN, Y.; BASHAN, L. E. How the plant growth-promoting bacterium Azospirillum promotes plant growth - a critical assessment. Advances in Agronomy, San Diego, v. 108, p. 77-136, 2010. https://doi.org/10.1139/w04-035

BASHAN, Y.; HOLGUIN, G.; DE-BASHAN, L. E. Review: Azospirillum plant relationships: physiological, molecular, agricultural, and environmental advances (1997-2003). Canadian Journal of Microbiology, Ottawa, v. 50, p. 521-577, 2004.

BODDEY, R. M.; POLIDORO, J. C.; RESENDE, A. S.; ALVES, B. J. R.; URQUIAGA, S. Use of ${ }^{15} \mathrm{~N}$ natural abundance technique for the quantification of the contribution of $\mathrm{N}_{2}$ fixation to sugar cane and others grasses. Australian Journal of Agricultural Research, Clayton, v. 28, 889-895, 2001.

CARMO, M. S.; CRUZ, S. C. S.; SOUZA, E. J.; CAMPOS, L. F. C.; MACHADO, C. G. Doses e fontes de nitrogênio no desenvolvimento e produtividade da cultura de milho doce (Zea mays convar. saccharata var. rugosa). Bioscience Journal, Uberlândia, v. 28, p. 223-231, 2012.

CASTRO, P. R. C.; KLUGE, R. A.; SESTARI, I. Manual de fisiologia vegetal: fisiologia de cultivos. São Paulo, Editora Agronômica Ceres, 2008. 864p.

CONAB - Companhia Nacional de Abastecimento. Acompanhamento da Safra Brasileira: grãos, nono levantamento, 2012. 80p.

COSTA, R. R. G. F.; QUIRINO, G. S. F.; NAVES, D. C. F.; SANTOS, C. B.; ROCHA, A. F. S. Efficiency of inoculant with Azospirillum brasilense on the growth and yield of second-harvest maize. Pesquisa Agropecuária Tropical, Goiânia, v. 45, n. 3, p. 304-311, 2015. https://doi.org/10.1590/1983$40632015 \mathrm{v} 4534593$

CHUBATSU, L. S.; MONTEIRO, R. A.; SOUZA, E. M.; OLIVEIRA, M. A .S.; YATES, M. G.; WASSEM, R.; BONATTO, A. C.; HUERGO, L. F.; .STEFFENS, M. B. R.; RIGO, L. U.; PEDROSA, F. O. Nitrogen fixation control in Herbaspirillum seropedicae. Plant and Soil, Crawley, v. 352, p. 197-207, 2012. https://doi.org/10.1007/s11104-011-0819-6

FERREIRA, D. F. Sisvar: a computer statistical analysis system. Ciência e Agrotecnologia, Lavras, v. 35, p. 1039-1042, 2011.

GOPALSWAMY, G.; VIDHYASEKARAN, P. Effect of Azospirillum lipoferum inoculation and inorganic nitrogen on wetland rice. Oryza, New Delhi, v. 26, p. 378-380, 1988.

HARTMANN, A.; MAHAVIR, S.; KLIGMALLER, W. Isolation and characterization of Azospirillum mutants excreting high amounts of indole acetic acid. Canadian Journal of Microbiology, Ottawa, v. 29, p. 916- 922, 1983. https://doi.org/10.1139/m83-147 
HUNGRIA, M.; CAMPO, R. J.; SOUZA, E. M.; PEDROSA, F. O. Inoculation with selected strains of Azospirillum brasilense and A. lipoferum improves yields of maize and wheat in Brazil. Plant and Soil, Crawley, v. 331, p. 413-425, 2010. https://doi.org/10.1007/s11104-009-0262-0

KAPPES, C.; ARF, O.; FERREIRA, J. P.; BEM, E. A. D.; PORTUGAL, J. R.; VILELA, R. G. Inoculação de sementes com bactéria diazotrófica e aplicação de nitrogênio em cobertura e foliar em milho. Semina: Ciências Agrárias, Londrina, v. 34, n. 2, p. 527-538, 2013. https://doi.org/10.5433/1679-0359.2013v34n2p527

MALAVOLTA, E. Manual de nutrição mineral de plantas. São Paulo: Editora Agronômica Ceres, 2006. 631p.

MORAIS, T. P.; BRITO, C. H.; BRANDÃO, A. M.; RESENDE, W. S. Inoculation of maize with Azospirillum brasilense in the seed furrow. Revista Ciência Agronômica, Fortaleza v. 47, n. 2, p. 290-298, 2016.

NERI, D. K. P.; MORAES, J. C.; GAVINO, M. A. Interação silício com inseticida regulador de crescimento no manejo da lagarta-do-cartucho Spodoptera frugiperda (J.E. Smith, 1797) (Lepidoptera: Noctuidae) em milho. Ciência e Agrotecnologia, Lavras, v. 29, p. 1167-1174, 2005.

QUADROS, P. D.; ROESCH, L. F. W.; SILVA, P. R. F.; VIEIRA, V. M.; ROEHRS, D. D.; CAMARGO, F. A. O. Desempenho agronômico a campo de híbridos de milho inoculados com Azospirillum. Revista Ceres, Viçosa, v. 61, p. 209-218, 2014.

RAIJ, B. V.; CANTARELLA, H.; QUAGGIO, J. A.; FURLANI, A. M. C. Recomendações de adubação e calagem para o estado de São Paulo. 2 ed. Campinas: Instituto Agronômico, 1996. 285p.

RAMOS, A. S.; SANTOS, T. M. C.; SANTANA, T. M.; GUEDES, E. L. F.; MONTALDO, Y. C. Ação do Azospirillum lispoferum no desenvolvimento de plantas de milho. Revista Verde, Mossoró, v. 5, p. 113-117, 2010.

REIS JUNIOR, F. B.; MACHADO, C. T. T.; MACHADO, A. T.; SODEK, L. Inoculação de Azospirillum amazonense em dois genótipos de milho sob diferentes regimes de nitrogênio. Revista Brasileira de Ciência do Solo, v. 32, p. 1139-1146, 2008. https://doi.org/10.1590/S0100-06832008000300022

REPKE, R. A.; CRUZ, S. J. S.; SILVA, C. J.; FIGUEIREDO, P. G.; BICUDO, S. J. Eficiência da Azospirillum brasilense combinada com doses de nitrogênio no desenvolvimento de plantas de milho. Revista Brasileira de Milho e Sorgo, Sete Lagoas, v.12, n.3, p. 214-226, 2013.

RIBAUDO, C. M.; RONDANINI, D. P.; CURÁ, J. A.; FRASCHINA, A. A. Response of Zea mays to the inoculation with Azospirillum on nitrogen metabolism under greenhouse conditions. Biologia Plantarum, Praha, v. 44, p. 631-634, 2001. https://doi.org/10.1023/A:1013779712106

NOVAKOWISK, J. H.; SANDINI, I. E.; FALBO, M. K.; MORAES, A.; NOVAKOWISKI, J. H.; CHENG, N. C. Efeito residual da adubação nitrogenada e inoculação de Azospirillum brasilense na cultura do milho. Semina: Ciências Agrárias, Londrina, v. 32, p. 1687-1698, 2011. https://doi.org/10.5433/16790359.2011v32Suplp1687 https://doi.org/10.5433/1679-0359.2011v32n4Sup1p1687

ZEMRANY, H.; CORTET, J.; LUTZ, M. P.; CHABERT, A.; BAUDOIN, E.; HAURAT, J.; MAUGHAN, N.; FÉLIX, D.; DÉFAGO, G.; BALLY, R.; MOËNNE-LOCCOZ, Y. Field survival of the phytostimulator Azospirillum lipoferum crt1 and functional impact on maize crop, biodegradation of crop residues, and soil faunal indicators in a context of decreasing nitrogen fertilization. Soil Biology and Biochemistry, Leicestershire, v. 38, p. 1712-1726, 2006. https://doi.org/10.1016/j.soilbio.2005.11.025

SALOMONE, I. E. G.; DÖBEREINER, J. Maize genotype effects on the response to Azospirillum inoculation. Biology and Fertility of Soils, Florence, v. 21, p. 193-196, 1996. https://doi.org/10.1007/BF00335934 
STANCHEVA, I.; DIMITROV, I.; KALOYANOVA, N.; DIMITROVA, A.; ANGELOV, M. Effects of inoculation with Azospirillum brasilense on photosynthetic 29 enzyme activities and grain yield in maize. Agronomie, Les Ulis, v. 12, p. 319-324, 1992. https://doi.org/10.1051/agro:19920405

TEODORO, P. E.; RIBEIRO, L. P.; CORREA, C. C. G.; LUZ JUNIOR, R. A. A.; CAPRISTO, D. P.; ZANUNCIO, A. S.; TORRES, F. E. Genetic divergence among maize hybrids in cerrado-pantanal ecotone. Bioscience Journal (Online), Uberlândia, v. 31, p. 1319-1324, 2015. http://dx.doi.org/10.14393/BJv31n5a2015-26236 https://doi.org/10.14393/BJ-v31n5a2015-26236 